\title{
AKTIVITAS ANTIOKSIDAN DAN EFEK HEPATOPROTEKTIF DAUN BAKAU API-API PUTIH
}

\section{Antioxidant Activity and Hepatoprotective Effect of Green Mangrove Leaves}

\author{
Safrina Dyah Hardiningtyas ${ }^{1 \star}$, Sri Purwaningsih ${ }^{1}$, Ekowati Handharyani ${ }^{2}$ \\ 1Departemen Teknologi Hasil Perairan, Fakultas Perikanan dan Ilmu Kelautan, \\ Institut Pertanian Bogor, Jalan Agatis, Bogor 16680 Jawa Barat \\ Telepon (0251) 8622909, 8622907, Faks. (0251) 8622907 \\ 2Departemen Klinik, Reproduksi, dan Patologi, Fakultas Kedokteran Hewan, \\ Institut Pertanian Bogor, Jalan Agatis Bogor 16680 Jawa Barat \\ Telepon (0251) 8629469, 8629470, Faks. (0251) 8629459 \\ *Korespodensi: saf.tyas@gmail.com \\ Diterima 21 Januari 2014/Disetujui 04 April 2014
}

\begin{abstract}
Abstrak
Penelitian ini bertujuan untuk mendapatkan ekstrak kasar daun api-api putih yang memiliki aktivitas antioksidan terbaik, menentukan kandungan fitokimia dan efek Hepatoprotektif ekstrak kasar yang dipilih secara in vivo. Daun api-api putih diekstrak menggunakan tiga jenis pelarut, yakni metanol, etil asetat dan n-heksana. Dalam uji in vivo dilakukan evaluasi terhadap kadar malondialdehid (MDA), enzim aspartat transaminase (AST), enzim alanin transaminase (ALT), dan histopatologi. Hasil penelitian menunjukkan bahwa ekstraksi daun api-api putih dengan pelarut etil asetat menghasilkan aktivitas antioksidan terbaik dengan kandungan fitokimia terdiri dari flavonoid dan steroid/triterpenoid. Pemberian ekstrak etil asetat daun api-api putih pada tikus yang telah diinduksi $\mathrm{CCl}_{4}$ dapat menormalkan berbagai parameter biokimia stres oksidatif (kadar MDA, AST, dan ALT) dibandingkan dengan standar Silymarin. Ekstrak daun apiapi putih berpotensi untuk melindungi hati tikus dari kerusakan oksidatif yang diinduksi $\mathrm{CCl}_{4}$. Efek Hepatoprotektif ekstrak daun api-api putih berkorelasi dengan aktivitas antioksidannya.
\end{abstract}

Kata kunci: antioksidan, Avicennia marina, ekstrak, hepatoprotektor

This research aimed to extractthe antioxidant compound of green Mangrove (Avicennia marina) leave and to test the effect hepato protective of crude extract selected in vivo model. In vivo test was performed by evaluated malondialdehyde (MDA) level, enzyme of aspartate transaminase (AST) dan alanine transaminase (ALT) level, and histopathology. The result showed that extraction A. marina leaf with ethyl acetate display the best antioxidant activity. Phytocemical of ethyl acetate extract of A.marina leaf contained flavonoid and steroid/triterpenoid.Treatment with ethyl acetate extract of A. marina leaves normalized various biochemical parameters of oxidative stress (MDA, AST, and ALT level) in compared to Silymarin standard. A. marina leaves extract could be proposed to protect the liver against $\mathrm{CCl}_{4}$-induced oxidative damage in rats. The hepatoprotective effect might be correlated with its antioxidant and free radical scavenger effects.

Keyword: antioxidant, Avicennia marina, extract, hepatoprotective

\section{PENDAHULUAN}

Hati adalah organ tubuh yang berfungsi dalam menetralisir zat toksik yang masuk dalam tubuh, serta menjadi sasaran peningkatan konsentrasi radikal bebas. Radikal bebas merupakan sekelompok zat kimia yang sangat reaktif karena memiliki satu atau lebih elektron yang tidak berpasangan (Halliwell dan Gutteridge 2007). Konsentrasi radikal bebas yang tidak seimbang dengan antioksidan dapat menimbulkan stres oksidatif pada tubuh. Stres oksidatif dapat menyebabkan peroksidasi 
lipida sehingga dapat menyebabkan kerusakan sel dan menimbulkan penyakit degeneratif, misalnya penyakit liver (Sen et al. 2010) sehingga perlindungan terhadap organ hati sangat diperlukan untuk mencegah kerusakan oksidatif yang berlanjut.

Kerusakan akibat radikal bebas dalam tubuh tersebut dapat diatasi dengan antioksidan. Antioksidan didefinisikan sebagai suatu substansi yang dapat menunda, mencegah, atau menghilangkan kerusakan oksidatif pada molekul target, contoh protein, lipida dan DNA (Halliwell dan Gutteridge 2007). Tubuh secara alami memproduksi zat antioksidan endogen yang mampu mengatasi efek radikal bebas, tetapi saat pasokan radikal bebas meningkat dibutuhkan pasokan zat antioksidan dari luar. Antioksidan dapat berasal dari bahan alami dan sintentik. Sumber antioksidan alami telah banyak dilaporkan berasal dari tanaman. Salah satu tanaman yang dapat dijadikan sebagai sumber antioksidan alami adalah bakau jenis api-api putih (Avicennia marina).

Bakau api-api putih merupakan salah satu jenis bakau yang tersebar di seluruh Indonesia dengan kondisi yang melimpah (Noor et al. 2006). Daun api-api putih dimanfaatkan oleh masyarakat pesisir sebagai bahan pangan dan obat-obatan. Pengalaman secara tradisional, bakau ini di beberapa daerah telah digunakan untuk sayuran serta mengobati berbagai jenis penyakit, contoh hepatitis, kusta, rematik, cacar, bisul, dan obat luka bakar (Bandaranayake 2002; Noor et al. 2006).

Hasil penelitian yang dilakukan oleh Bunyapraphatsara et al. (2004); Vadlapudi dan Naidu (2009) menunjukkan bahwa daun api-api putih memiliki aktivitas antioksidan. Berdasarkan pemahaman tersebut, diperoleh suatu pemikiran bahwa dengan memperoleh senyawa bioaktif ekstrak daun api-api putih yang memiliki aktivitas antioksidan, maka dapat berpotensi untuk menanggulangi kerusakan oksidatif pada hati. Penelitian ini bertujuan untuk mendapatkan ekstrak kasar daun api-api putih yang memiliki aktivitas antioksidan terbaik, menentukan kandungan fitokimia dan efek Hepatoprotektif ekstrak kasar yang dipilih secara in vivo.

\section{BAHAN DAN METODE Bahan dan Alat}

Bahan yang digunakan adalah daun bakau api-api putih yang diambil di Kawasan Hutan Mangrove Blanakan, Subang, bahan kimia untuk ekstraksi daun api-api putih, pengujian antioksidan, antioksidasi lipida (kadar malondialdehida, enzim aspartat transaminase (AST), enzim alanin transaminase (ALT)), dan histopatologi hati hewan coba. Peralatan yang digunakan pada penelitian ini adalah timbangan analitik (Max $410 \mathrm{~g}$ and HF400), vakum rotari evaporator (Buchi Rotavapor R-210), dan spektofotometer (UV-Vis RS UV2500).

\section{Metode Penelitian}

Penelitian ini dilakukan dalam dua tahap percobaan. Tahap pertama adalah preparasi, ekstraksi, dan analisis aktivitas antioksidan. Tahap dua adalah pengujian efek Hepatoprotektif daun api-api putih secara in vivo.

\section{Preparasi Sampel Daun Api-api Putih}

Sampel daun api-api putih dikumpulkan dan dibersihkan dari kotoran menggunakan akuades, kemudian dilakukan pengeringan. Proses pengeringan dilakukan menggunakan sinar matahari selama 4 hari. Daun apiapi putih kering dijadikan serbuk halus menggunakan mesin penepung dengan saringan sebesar 100 mesh. Serbuk daun bakau api-api putih kering kemudian diekstraksi dengan perlakuan jenis pelarut.

\section{Ekstraksi dan Pengujian Antioksidan}

Ekstraksi secara tunggal dilakukan dengan metode maserasi menggunakan pelarut metanol, etil asetat atau n-heksana p.a dengan perbandingan sampel dan pelarut 1:5 (b/v) selama 24 jam.Tahap selanjutnya, dilakukan filtrasi untuk memisahkan pelarut dengan sampel. Filtrat yang terkumpul dipisahkan antara pelarut dan ekstraknya 
menggunakan vacum rotary evaporator pada suhu $37^{\circ} \mathrm{C}$ hingga diperoleh ekstrak kasar berbentuk pasta. Ketiga sampel tersebut diuji aktivitas antioksidan dengan metode (DPPH) (Hanani et al. 2005). Ekstrak kasar daun apiapi putih yang memiliki aktivitas antioksidan terbaik dianalisis fitokimia menurut metode Harbone (1987), untuk mengetahui golongan senyawa bioaktif pada ekstrak tersebut.

\section{Pengujian Efek Hepatoprotektif secara In Vivo}

Tikus putih Sprague Dawley berumur 8 minggu dengan berat badan (180-210) g yang digunakan pada percobaan terlebih dahulu diadaptasikan dalam kandang selama kurang lebih satu minggu sebelum digunakan untuk penelitian. Tikus diberi pakan standar dan minum ad libitum selama percobaan dilakukan. Tikus ditimbang dan dikelompokkan menjadi 4 kelompok $(\mathrm{n}=3)$ di dalam kandang secara terpisah pada hari terakhir adaptasi. Kelompok perlakuan adalah sebagai berikut:

Kelompok 1: Kontrol negatif (normal)

Kelompok 2: Kontrol positif, yaitu tikus diinduksi $\mathrm{CCl}_{4}$ dengan dosis $0,5 \mathrm{~mL} / \mathrm{kg} \mathrm{BB}$ secara intraperitonial (Sengupta et al. 2011) pada hari pertama.

Kelompok 3: Perlakuan ekstrak daun api-api terpilih. Tikus diinduksi pada hari pertama, kemudian diberikan ekstrak apiapi terpilih (dilarutkan dalam 0,5\% Tween 80) secara oral sebanyak $0,5 \mathrm{~mL}$ pada hari ke-2 sampai hari ke-8. Dosis ekstrak yang diberikan merupakan konversi dari nilai $\mathrm{IC}_{50}$ pada uji in vitro.

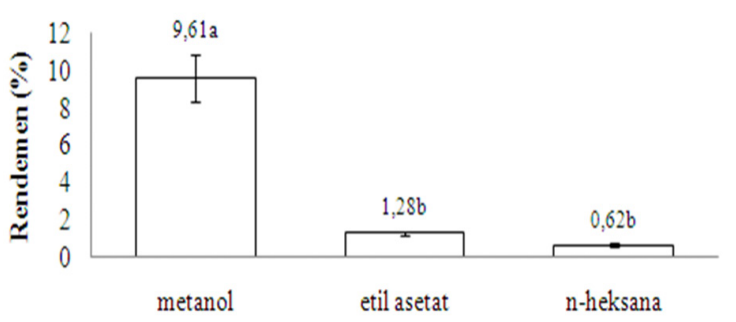

Gambar 1 Rendemen hasil ekstraksi dengan jenis pelarut berbeda.
Kelompok 4: Perlakuan hepatoprotektor standar, yaitu silymarin. Tikus diinduksi pada hari pertama, kemudian diberikan silymarin (dilarutkan dalam 0,5\% Tween 80 ) dosis 25 $\mathrm{mg} / \mathrm{kg}$ BB secara oral pada hari ke-2 sampai hari ke-8.

Sampel darah digunakan untuk menganalisis kadar enzim AST dan enzim ALT (kit AMP diagnostic ${ }^{\circ}$ ), sedangkan hati untuk pengamatan preparat histopatologi hati (Kiernan 1990) dan analisis kadar MDA (Capeyron et al. 2002).

\section{Analisis data}

Data pengujian rendemen ekstrak, aktivitas antioksidan, kadar MDA, kadar enzim AST dan enzim ALT dianalisis dengan analisis ragam menggunakan rancangan acak lengkap (RAL). Untuk melihat perbedaan antar perlakuan dilakukan pengujian lanjut menggunakan uji Tukey. Data kandungan fitokimia dan gambaran histopatologi dianalisis secara deskriptif dan kuantitatif.

\section{HASIL DAN PEMBAHASAN Aktivitas Antioksidan Ekstrak Daun Api- api Putih}

Jenis pelarut yang digunakan merupakan faktor utama yang menentukan hasil ekstraksi atau rendemen ekstrak. Rendemen hasil ekstraksi dengan jenis pelarut berbeda disajikan pada Gambar 1, sedangkan hubungan jenis pelarut dengan aktivitas antioksidan (rataan $\mathrm{IC}_{50}$ ) ekstrak daun api-api putih disajikan pada Gambar 2.

Ekstrak etil asetat menunjukkan aktivitas antioksidan terbaik, namun aktivitas

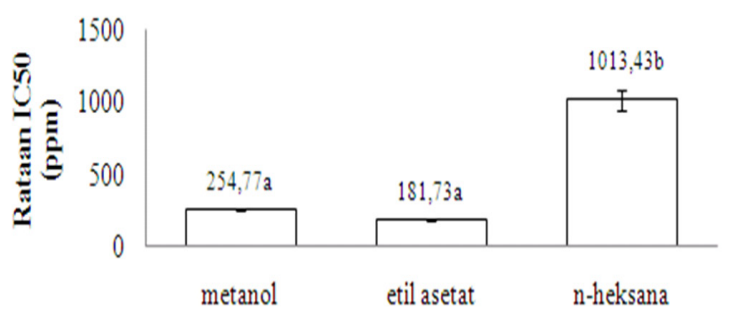

Gambar 1 Hubungan jenis pelarut dengan aktivitas antioksidan (nilai $\mathrm{IC}_{50}$ ) ekstrak daun bakau api-api putih 
antioksidan ekstrak kasar daun bakau api-api tersebut masih lebih rendah dibandingkan dengan aktivitas antioksidan $\mathrm{BHT}$ dan vitamin $\mathrm{C}$ dengan nilai $\mathrm{IC}_{50}$ masing-masing sebesar 5,86 ppm dan 8,26 ppm. Perbedaan aktivitas antioksidan pada setiap ekstrak tersebut diduga berkaitan dengan tipe antioksidan yang terkandung di dalamnya. Menurut Yang et al. (2011), tipe antioksidan berdasarkan kelarutannya terdiri dari antioksidan lipofilik (larut dalam nonpolar) dan antioksidan hidrofilik (larut dalam polar).

Aktivitas antioksidan ekstrak etil asetat yang paling tinggi dibandingkan dengan ekstrak yang lain diduga disebabkan oleh pelarut etil asetat yang bersifat semipolar sehingga mengandung senyawa aktif antioksidan baik yang bersifat hidrofilik maupun lipofilik. Menurut Cano et al. (2003), etil asetat dapat digunakan untuk mengekstrak komponen lipofilik dari fase aqueous serta diduga mampu mengekstraksi beberapa komponen hidrofilik dari fase aqueous. Pelarut $n$-heksana digunakan untuk mengekstrak komponen lipofilik dari fase aqueous, sedangkan metanol mengekstrak komponen hidrofilik dari fase aqueous.

Yeum et al. (2004; 2009) menyatakan bahwa antioksidan hidrofilik dan lipofilik dapat bekerja secara sinergis sehingga memiliki kemampuan yang kuat dalam melindungi sistem biologis dan mengurangi kerusakan yang disebabkan oleh reactive oxygen species (ROS). Antioksidan lipofilik contoh tokoferol, sebagai penangkap radikal oksigen yang dapat menghambat inisiasi dan propagasi pada reaksi rantai oksidatif dalam sistem hidrofobik. Menurut Wu et al. (2004), antioksidan hidrofilik terutama komponen fenolik bekerja secara mudah dalam mendonorkan satu atom hidrogen pada ROO•.

\section{Kandungan Fitokimia Ekstrak Terpilih}

Kandungan fitokimia ekstrak etil asetat daun bakau api-api putih yang diduga berperan sebagai antioksidan adalah flavonoid dan steroid atau triterpenoid (Tabel 1). Menurut Setzer (2008), triterpenoid atau steroid merupakan senyawa aktif yang termasuk dalam jenis antioksidan lipofilik. Menurut Middleton et al. (2000), flavonoid merupakan senyawa aktif yang termasuk dalam jenis intermediet antioksidan yang berperan sebagai antioksidan hidrofilik dan lipofilik. Flavonoid merupakan senyawa yang berperan sebagai antioksidan. Mekanisme antioksidan dari flavonoid adalah menangkap ROS secara langsung, mencegah regenerasi ROS dan secara tidak langsung dapat meningkatkan aktivitas antioksidan enzim antioksidan seluler (Akhlaghi dan Bandy 2009). Flavonoid merupakan senyawa yang paling efektif sebagai scavanger spesies reaktif, misalnya super dioksida, radikal peroksil, dan peroksinitrit dengan cara mentransfer atom H+ (Middleton et al. 2000; Akhlaghi dan Bandy 2009). Pencegahan terbentuknya ROS oleh flavonoid dilakukan dengan beberapa cara, yaitu menghambat kerja enzim xantin oksidase dan Nicotinamide Adenine Dinucleotide Phosphate (NADPH) oksidase, serta mengkelat logam ( $\mathrm{Fe} 2+$ dan $\mathrm{Cu} 2+$ ) sehingga dapat mencegah reaksi redoks yang dapat menghasilkan radikal bebas (Akhlaghi dan Bandy 2009; Atmani et al. 2009).

Menurut Lotito dan Fraga (2000), flavonoid merupakan antioksidan yang berperan dalam melindungi antioksidan lipofilik sehingga dapat menguatkan

Tabel 1 Kandungan fitokimia eksrak etil asetat daun bakau api-api putih

\begin{tabular}{lc}
\hline \multicolumn{1}{c}{ Analisis Fitokimia } & Hasil \\
\hline a. Alkaloid & \\
- Wagner & - \\
- Meyer & - \\
- Dragendorf & - \\
b. Steroid/Triterpenoid & + \\
c. Flavonoid & + \\
d. Saponin (uji busa) & - \\
\hline Keterangan: +: ada - : tidak ada &
\end{tabular}


antioksidan seluler. Beberapa penelitian juga menunjukkan bahwa aktivitas antioksidan flavonoid berkaitan erat dengan pencegahan timbulnya beberapa penyakit, misalnya penyakit kardiovaskular (Akhlaghi dan Bandy 2009), kanker/tumor (Brusselmans et al. 2004), dan penyakit liver (Jin et al. 2010; Pinzaru et al. 2011).

Tabel 1 menunjukkan bahwa kandungan fitokimia ekstrak etil asetat daun bakau apiapi putih yang diduga berperan sebagai antioksidan adalah flavonoid dan steroid atau triterpenoid. Menurut Setzer (2008), triterpenoid atau steroid merupakan senyawa aktif yang termasuk dalam jenis antioksidan lipofilik. Menurut Middleton et al. (2000), flavonoid merupakan senyawa aktif yang termasuk dalam jenis intermediet antioksidan yang berperan sebagai antioksidan hidrofilik dan lipofilik.

Flavonoid merupakan senyawa yang berperan sebagai antioksidan. Mekanisme antioksidan dari flavonoid adalah menangkap ROS secara langsung, mencegah regenerasi ROS, dan secara tidak langsung dapat meningkatkan aktivitas antioksidan enzim antioksidan seluler (Akhlaghi dan Bandy 2009). Flavonoid merupakan senyawa yang paling efektif sebagai scavanger spesies reaktif, misalnya super dioksida, radikal peroksil, dan peroksinitrit dengan cara mentransfer atom $\mathrm{H}+$ (Middleton et al. 2000; Akhlaghi dan Bandy 2009). Pencegahan terbentuknya ROS oleh flavonoid dilakukan dengan beberapa cara, yaitu menghambat kerja enzim xantin oksidase dan Nicotinamide Adenine Dinucleotide Phosphate (NADPH) oksidase, serta mengkelat logam $\left(\mathrm{Fe}^{2+}\right.$ dan $\left.\mathrm{Cu}^{2+}\right)$ sehingga dapat mencegah reaksi redoks yang dapat menghasilkan radikal bebas (Akhlaghi dan Bandy 2009; Atmani et al. 2009).

Lotito dan Fraga (2000) menyatakan bahwa flavonoid merupakan antioksidan yang berperan dalam melindungi antioksidan lipofilik sehingga dapat menguatkan antioksidan seluler. Beberapa penelitian juga menunjukkan bahwa aktivitas antioksidan flavonoid berkaitan erat dengan pencegahan timbulnya beberapa penyakit, misalnya penyakit kardiovaskular (Akhlaghi dan Bandy 2009), kanker atau tumor (Brusselmans et al. 2004), dan penyakit liver (Jin et al. 2010; Pinzaru et al. 2011).

Triterpenoid atau steroid merupakan senyawa yang memiliki peranan sebagai antioksidan. Menurut Topcua et al. (2007), mekanisme antioksidan dari triterpenoid adalah dengan cara menangkap/scavenging spesies reaktif, misalnya superoksida, dan mengkelat logam $\left(\mathrm{Fe}^{2+}\right.$ dan $\left.\mathrm{Cu}^{2+}\right)$. Hasil penelitian Abrosca et al. (2006) menunjukkan bahwa senyawa triterpenoid dari Annurca aple memiliki aktivitas sebagai antioksidan dan dapat menghambat peroksidasi lipida. Aktivitas biologi dari triterpenoid/ steroid selain antioksidan adalah sebagai hepatoprotektor dan analgesik (Fai dan Tao 2009), antitumor (Feng et al. 2006), antiproliferatif (Nugraheni et al. 2011), dan memberikan efek imunodulator (Martin 2006).

\section{Analisis Efek Hepatoprotektor dari Ekstrak Etil Asetat Daun Bakau Api-api Putih}

Hepatoprotektor adalah senyawa atau zat yang berkhasiat melindungi sel sekaligus memperbaiki jaringan hati yang rusak akibat pengaruh zat toksik (Panjaitan 2008). Pemberian hepatoprotektor dapat dilakukan untuk pencegahan (preventif) atau penyembuhan (kuratif) (Kumarappan et al. 2011). Penelitian ini mengamati efek hepatoprotektor ekstrak daun bakau apiapi putih secara kuratif, hal ini berdasarkan pengetahuan masyarakat yang secara tradisional memanfaatkan bakau api-api putih sebagai obat hepatitis.

Karbon tetraklorida merupakan senyawa kimia yang digunakan dalam penelitian ini sebagai hepatotoksin. Menurut Al-Shabanah et al. (2000), karbon tetraklorida $\left(\mathrm{CCl}_{4}\right)$ adalah agen hepatotoksik yang menghasilkan radikal bebas triklorometil $\left(\mathrm{CCl}_{3}\right)$, yang ketika diinduksi pada hati tikus sangat mirip 
dengan sirosis pada manusia. Suja et al. (2004) melaporkan bahwa perubahan yang berhubungan dengan kerusakan hati akibat induksi $\mathrm{CCl}_{4}$ sangat mirip dengan perubahan pada pasien hepatitis virus akut. Beberapa parameter perubahan yang diamati pada penelitian ini adalah kadar malondialdehida (MDA) pada hati, kadar enzim serum AST dan (ALT) serta histopatologi hati.

\section{Kadar MDA pada Hati}

Malondialdehida (MDA) merupakan senyawa sitotoksik yang dihasilkan dari proses peroksidasi lipid, pada akhir tahapan peroksidasi (Huang et al. 2011). Pengukuran MDA digunakan sebagai indikator kerusakan oksidatif asam lemak tak jenuh pada sel yang menyebabkan langsung perubahan struktur dan fungsi (Klaunig et al. 2009). Kadar MDA pada hati dari kelompok tikus yang diberikan perlakuan disajikan pada Gambar 3.

Hasil analisis ragam menunjukkan bahwa perlakuan yang diberikan pada tikus memberikan pengaruh yang nyata terhadap kadar MDA hati $(\mathrm{p}<0,05)$. Hasil uji lanjut menunjukkan bahwa terjadi peningkatan kadar MDA pada tikus yang diinduksi $\mathrm{CCl}_{4}$. Kadar MDA mengalami penurunan setelah diberikan ekstrak etil asetat daun bakau api-api putih dan sylimarin $(\mathrm{p}<0,05)$. Hal ini menunjukkan bahwa ada indikasi perlindungan dan penghambatan peroksidasi lipida yang berlanjut oleh ekstrak etil asetat. Efek penghambatan peroksidasi lipida pada ekstrak etil asetat daun bakau api-api putih

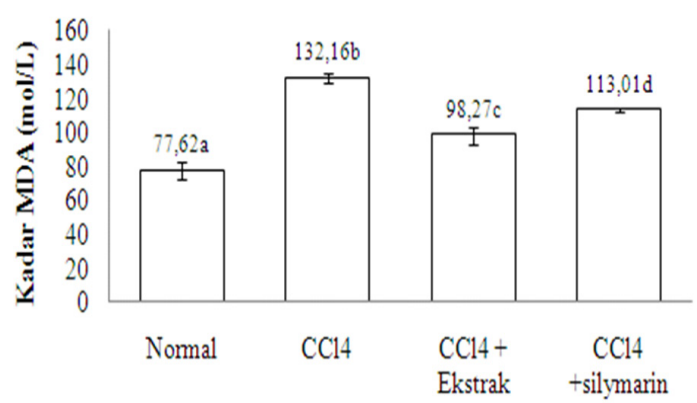

Gambar 3 Kadar MDA pada hati dari kelompok tikus yang diberikan perlakuan. disebabkan oleh sifat antioksidan senyawa flavonoid dan steroid/triterpenoid yang terkandung didalamnya.

Menurut Akhlaghi dan Bandy (2009); Topcua et al. (2007), triterpenoid dan flavonoid merupakan senyawa yang bersifat antioksidan yang dapat mengatasi dan mencegah radikal bebas. Hasil penelitian Nugraheni et al. (2011) menunjukkan bahwa triterpenoid dapat menghambat peroksidasi lipid pada tahap inisiasi dengan menghambat radikal peroksil serta di tahap akhir dengan menghambat produk sekunder, misalnya malondialdehid. Bastona dan Leroux (2007); Ghosh et al. (2010) melaporkan triterpenoid dapat menghambat aktivitas enzim sitokrom $\mathrm{P}_{450}$ sehingga proses peroksidasi lipid akibat radikal bebas dapat dicegah. Hasil penelitian Androutsopoulos et al. (2010); Quintieri et al. (2011) juga menunjukkan bahwa flavonoid dapat menghambat aktivitas enzim sitokrom $\mathrm{P}_{450^{\circ}}$.

\section{Kadar AST dan ALT Darah Tikus}

Kadar enzim serum AST dan ALT merupakan parameter klinis yang menggambarkan intergritas sel hati (hepatosit) (Giannini et al. 2005). Hasil pengukuran kadar AST dan ALT darah tikus dalam serum tikus jantan strain Sprague Dawley $(\mathrm{n}=3)$ disajikan pada Gambar 4. Hasil analisis ragam menunjukkan bahwa perlakuan yang diberikan pada tikus berpengaruh nyata $(\alpha=0,05)$ pada kadar enzim AST serum. Hasil uji lanjut menunjukkan bahwa induksi $\mathrm{CCl}_{4}$ sebanyak $0,5 \mathrm{~mL} / \mathrm{kg} \mathrm{BB}$ mengakibatkan terjadinya peningkatan kadar enzim AST serum. Kadar enzim AST serum pada kelompok tikus yang induksi $\mathrm{CCl}_{4}$ dan kelompok normal berbeda secara nyata $(\mathrm{p}<0,05)$. Peningkatan kadar enzim AST serum pada kelompok tikus yang induksi $\mathrm{CCl}_{4}$ tersebut secara keseluruhan tidak terlalu mencolok, hanya satu kali lipat dari kelompok normal. Peningkatan tersebut masih dalam kategori "mild" atau ringan (kenaikan amino transferase 1-3 kali lipat) (Thapa dan Walia 2007). 

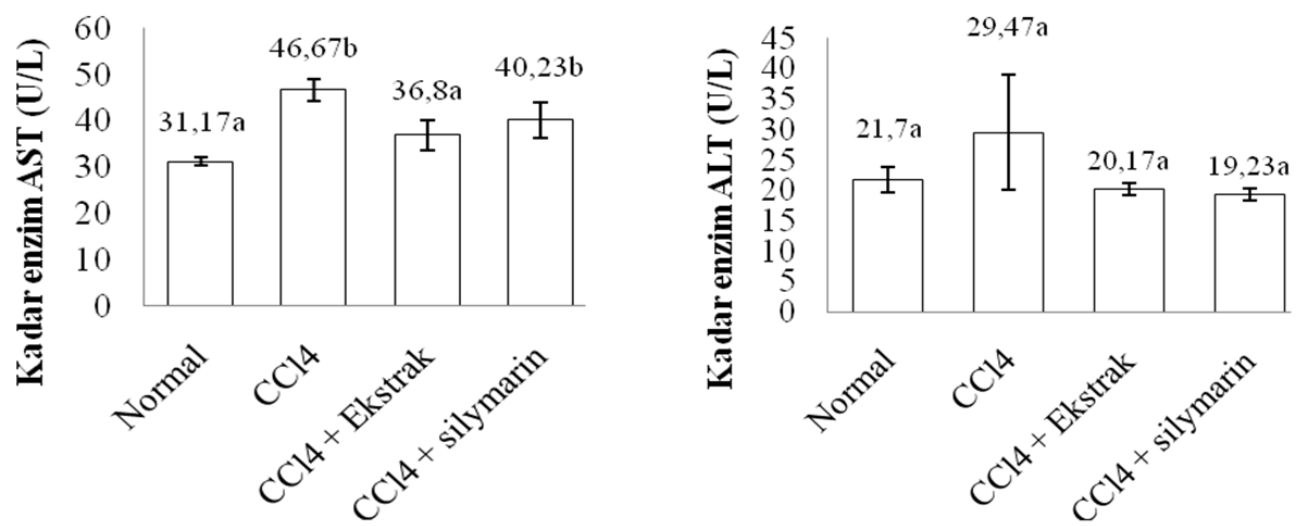

Gambar 4 Rataan pengukuran kadar enzim AST (A) dan enzim ALT (B) dalam serum tikus jantan strain Sprague Dawley $(\mathrm{n}=3)$.

Hasil analisis ragam menunjukkan bahwa perlakuan yang diberikan pada tikus tidak berpengaruh nyata, $(\mathrm{p}<0,05)$ pada kadar enzim ALT serum, walaupun demikian ada indikasi perubahan kadar enzim ALT serum pada tikus yang telah diinduksi $\mathrm{CCl}_{4}$ dan diberi ekstrak etil asetat daun api-api putih. Hasil tersebut menunjukkan bahwa ekstrak etil asetat mampu memberikan perlindungan atas kerusakan pada sel hati yang disebabkan oleh radikal bebas yang dihasilkan oleh metabolisme $\mathrm{CCl}_{4}$.

Menurut Giannini et al. (2005), kadar enzim ALT dan AST dalam darah tersebut mencerminkan kerusakan yang terjadi di dalam sel-sel hati. Enzim ALT dan AST merupakan enzim yang mengkatalis transfer grup a-amino dari alanin dan aspartat menuju grup asam $\alpha$-ketogutarat untuk membentuk oksaloasetat dan asam piruvat. Enzim ini banyak terdapat dalam hati. Enzim ALT terdapat pada sitosol sedangkan enzim AST terdapat dalam sitosol dan mitokondria. Hasil penelitian Badria et al. (2011) menunjukkan bahwa tikus yang diinduksi $\mathrm{CCl}_{4}$ akan mengalami peningkatan kadar enzim AST dan ALT serum. Kadar AST dan ALT serum berkorelasi dengan terjadinya inflamasi, steatosis, nekrosis, dan fibrosis pada hati tikus. Stockham dan Scott (2002) berpendapat bahwa kadar enzim AST di dalam darah akan meningkat bila terjadi kerusakan sel hati yang parah dan disertai nekrosis sehingga enzim dari mitokondria juga ikut keluar sel.

Perubahan kadar enzim AST dan ALT serum pada kelompok tikus yang diberikan ekstrak etil asetat daun api-api diduga berkaitan dengan kandungan senyawa ekstrak, yaitu flavonoid dan triterpenoid/ steroid yang berperan sebagai antioksidan. Antioksidan merupakan suatu senyawa yang dapat menetralisir suatu radikal bebas. Menurut Wang et al. (2004), bahwa senyawasenyawa golongan triterpenoid bersifat antioksidan sehingga mampu mengurangi jumlah metabolit $\mathrm{CCl}_{4}$ sehingga sel-sel hati dapat terlindungi dari kerusakan dan stabilitas membran sel hati serta aktivitasnya tetap terjaga. Sharma dan Shukla (2011) menyatakan bahwa efek antioksidan flavonoid adalah dapat meningkatkan proses regenerasi.

\section{Gambaran Histopatologi Hati Tikus}

Kerusakan oksidatif pada hati tikus dapat dilihat dengan gambaran histopatologinya. Gambaran keadaan histopatologis hati semua tikus pada setiap kelompok yang diamati dengan perbesaran 4000 kali dapat dilihat pada Gambar 4.

Gambar 4 menunjukkan bahwa ada perbedaan kondisi histopatologi hati pada setiap kelompok tikus. Hasil pengamatan mikroskopik sel hati pada kelompok normal (Gambar 4A) menunjukkan bahwa tidak ada perubahan yang spesifik; 


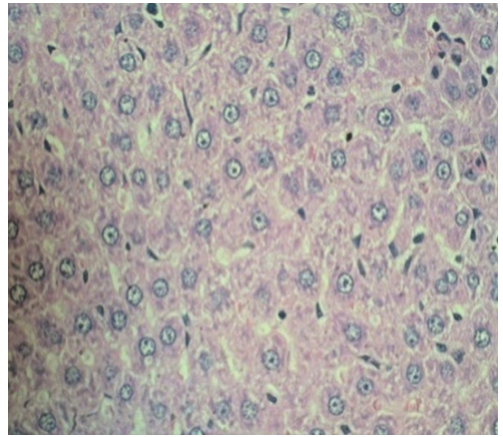

(a)

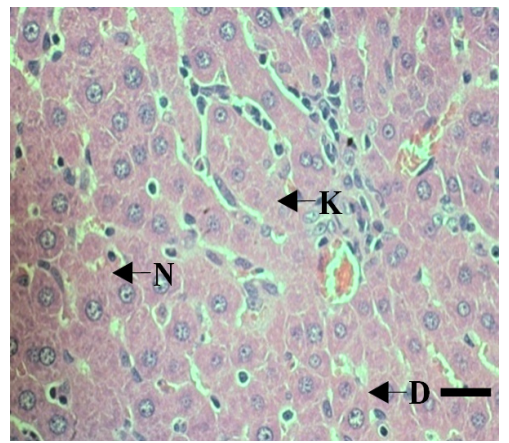

(c)

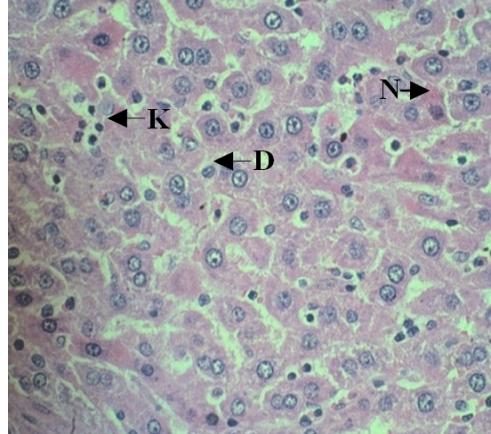

(b)

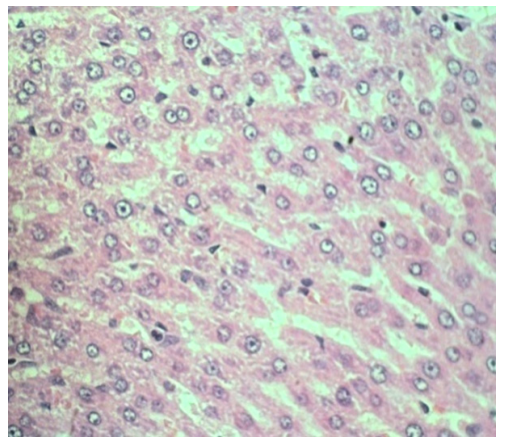

(d)

Gambar 4 Histopatologi hati tikus pada kelompok normal (A), kelompok yang diberi CCl4 (B), selanjutnya ekstrak etil asetat daun bakau api-api putih (C), silymarin dosis $25 \mathrm{mg} / \mathrm{kg}$ BB (D). Pewarnaan H\&E. Keterangan: degenerasi sel (D), sel nekrosis (N), sel Kupffer (K). $(\mathrm{Bar}=30 \mu \mathrm{m})$.

sel hati memiliki inti dan sitoplasma yang jelas. Sel-sel hepatosit tersusun teratur dengan jarak yang sama. Gambaran histopatologi sel hati pada kelompok yang diinduksi $\mathrm{CCl}_{4} 0,5 \mathrm{~mL} / \mathrm{kg} \mathrm{BB}$ (Gambar 4B) menunjukkan banyak sel yang mengalami degenerasi, nekrosis (kematian sel), serta terjadi infiltrasi sel Kupffer yang aktif pada daerah sinusoid.

Degenerasi sel ditandai oleh bentuk sel yang abnormal yang ditunjukkan oleh sel yang membesar, inti sel membesar, inti sel mengecil, bahkan sitoplasma sudah tidak berinti. Nekrosis sel ditandai dengan terlihatnya inti sel yang mengalami penyusutan dan warna sitoplasma menjadi gelap. Sel Kupffer yang aktif menandakan adanya senyawa toksik yang masuk ke dalam jaringan, misalnya $\mathrm{CCl}_{4}$, kemudian ada usaha fagositosis oleh sel-sel pertahanan lokal. Menurut Jaeschke et al. (2002), sel Kupffer berfungsi dalam proses fagositosis, selain itu sel ini berperan dalam menghasilkan mediator sitotoksik misalnya ROS dan mediator pro-inflamasi, misalnya sitokin dan kemokin.

Hasil dari beberapa penelitian menunjukkan bahwa induksi $\mathrm{CCl}_{4}$ dapat menyebabkan kerusakan sel yang ditandai dengan perubahan histopatologisel. Muriel et al. (2001) berpendapat bahwa induksi $\mathrm{CCl}_{4}$ menyebabkan aktifnya sel Kupffer, yang dapat memediasi kerusakan hati dan memicu terjadinya peroksidasi pada hati. Menurut Al-Shabanah et al. (2000), $\mathrm{CCl}_{4}$ dapat menyebabkan peroksidasi lipid sehingga dapat menurunkan intergritas sel sampai menyebabkan nekrosis sel. Hasil penelitian Panjaitan (2008) menunjukkan bahwa induksi $\mathrm{CCl}_{4} \quad 0,1 \mathrm{~mL} / \mathrm{kg} \quad \mathrm{BB}$ menyebabkan degenerasi sel-sel hati, bahkan pada kelompok yang mendapatkan $\mathrm{CCl}_{4}$ (1 dan 10) $\mathrm{mL} / \mathrm{kg}$ BB mengalami steatosis multifokal (akumulasi lemak 
pada sel hati).

Hasil pengamatan mikroskopik kelompok yang diberi perlakuan ekstrak etil asetat daun bakau api-api putih dosis 182 ppm sebanyak 0,5 mL (Gambar 4C) dan perlakuan silymarin dosis $25 \mathrm{mg} / \mathrm{kg}$ BB (Gambar 4D) menunjukkan adanya efek perlindungan dan pemulihan sel hati dari $\mathrm{CCl}_{4}$. Hasil tersebut ditandai oleh respon degenerasi dan nekrosis dalam jumlah yang sedikit. Degenerasi sel adalah penurunan fungsi sel yang bersifat reversible maupun irreversible. Pemberian ekstrak etil asetat dan silymarin tersebut diduga dapat mengembalikan fungsi sel hati sehingga peningkatan jumlah sel yang nekrosis atau sel irreversible dapat dicegah.

Efek perlindungan dan pemulihan pada tikus yang diberi ekstrak etil asetat daun bakau api-api putih diduga berkaitan dengan kandungan senyawa antioksidan yang terdapat pada ekstrak tersebut. Menurut Bastona dan Leroux (2007), senyawa golongan triterpenoid memiliki kemampuan dalam memelihara stabilitas membran sel hati sebagai antioksidan dan scavanger terhadap ROS. Menurut Sharma dan Shukla (2011), efek antioksidan flavonoid meningkatkan proses regenerasi dengan cara mendestruksi radikal bebas, menyediakan substrat kompetitif untuk lipid tak jenuh dalam membran dan atau mempercepat mekanisme perbaikan membran sel yang rusak.

Hasil penelitian Sahreen et al. (2011) menunjukkan bahwa efek Hepatoprotektif ekstrak metanol daun Carissa opaca pada tikus yang diinduksi $\mathrm{CCl}_{4}$ secara signifikan disebabkan oleh kandungan antioksidan dan kandungan penstabil membran sel pada ekstrak tersebut. Menurut Karthikeyan et al. (2008), efek hepatoprotektor ekstrak alga coklat Padina boergesenii ditunjukkan oleh kemampuan ekstrak tersebut dalam menghambat peroksidasi lipid dan menurunkan kadar enzim amino transferase (AST dan ALT). Punitha dan Rajasekaran (2011) melaporkan bahwa hepatoprotektor dapat memperbaiki integritas sel dan menstimulus aktivitas antioksidan enzim (superoksida dismutase, katalase, dan glutation peroksidase).

\section{KESIMPULAN}

Kondisi ekstraksi terbaik untuk mendapatkan aktivitas antioksidan daun bakau api-api putih menggunakan pelarut etil asetat selama 24 jam memiliki potensi sebagai hepatoprotektor, karena dapat menurunkan kadar MDA hati, kadar enzim AST dan ALT darah, serta mengurangi lesio histopatologi jaringan hati.

\section{DAFTAR PUSTAKA}

Abrosca BD, Fiorentino A, Monaco P, Oriano P, Pacifico S. 2006. Annurcoic acid: a new antioxidant ursane triterpene from fruits of cv. Annurca apple. Food Chemistry 98: 285-290.

Achiliya GS, Wadodkar SO, Dorle AK. 2004. Evaluation of hepatoprotective effect of Amakadi ghrita against carbon tetrachloride induced hepatic damage in rats. Journal Ethnopharmacology 90: 229-232.

Akhlaghi M, Bandy B. 2009. Review article: mechanisms of flavonoid protection against myocardial ischemiareperfusion injury. Journal Molecullar and Cellular Cardiology 46: 309-317.

Al-Shabanah OA, Alam K, Nagi MN, AlRikabi AC, Al-Bekairi AM. 2000. Protective effect of aminoguanidine, a nitric oxide synthase inhibitor against $\mathrm{CCl}_{4}$-induced hepatotoxicity in mice. Life Science 66: 265-270.

Androutsopoulos VP, Papakyriakou A, Vourloumis D, Tsatsakis AM, Spandidos DA. 2010. Dietary flavonoids in cancer therapy and prevention: substrates and inhibitors of cytochrome $\mathrm{P}_{450}$ CYP1 enzymes. Pharmacology and Theraphy 
126:9-20.

Atmani D, Chaher N, Atmani D, Berboucha M, Debbache N, Boudaoud H. 2009. Flavonoids in human health: from structure to biological activity. Current Nutrition and Food Science 5:225-237.

Badria AF, El-Belbasi HI, Sobh MM, Badria FA. 2011. Parallelism study between biochemical, immunological and histochemical parameters of liver injury induced by carbon tetrachloride on rats. Journal American Science 7(5): 581-591.

Bandarnayake WM. 2002. Bioactivities, bioactive compounds and chemical constituents of mangrove plants. Wetlands Ecology Management 10: 421-452

Bastona E, Leroux FR. 2007. Inhibitors of steroidal cytochrome $\mathrm{P}_{450}$ enzymes as targets for drug development. Recent Patents on Anti-Cancer Drug Discovery 2:31-58.

Bunyapraphatsara N, Jutiviboonsuk A, Sornlek P, Therathanathorn W, Aksornkaew S, Fong HHS, Pezzuto JM, KosmederJ. 2004. Pharmacological studies of plants in the mangrove forest. Thai Journal Phytopharmacy 10(2):112.

Brusselmans K, Vrolix R, Verhoeven G, Swinnen JV. 2004. Induction of cancer cell apoptosis by flavonoids is associated with their ability to inhibit fatty acid synthase activity. The Journal Biology Chemistry 280(7):5636-5645.

Cano A, Acosta M, Arnao MB. 2003. Hydrophilic and lipophilic antioxidant activity changes during on-vine ripening of tomatoes (Lycopersicon esculentum Mill.). Postharvest Biology and Technology 28: 59-65.

Capeyron, Julie C, Eric B, Jean P, Piere MR, Claude LL, Benard D. 2002 A diet cholesterol and deflcient in vite incudes lipid peroxidation but does not enhace antioxidant enzyme expression in rat liver. Biochemisrtry 13: 296-301.

Fai YM, Tao CC. 2009. Literature review onpharmacutical activities of oleanolic acid. Natural Product Medica 2: 291 298.

Feng Y, Li XM, Duan XJ, Wang BG. 2006. A new acylated iridoid glucoside from Avicennia marina. Chinese Chemical Letters 17(9): 1201-1204.

Ghosh J, Das J, Manna P, Sil PC. 2010. Arjunolic acid, a triterpenoid saponin, prevents acetaminophen (APAP)induced liver and hepatocyte injury via the inhibition of APAP bioactivation and JNK-mediated mitochondrial protection. Free Radical Biology Medicine 48(4): 535-553.

Giannini EG, Testa R, Savarino V. 2005. Liver enzyme alteration: a guide for clinicians. CMAJ 172(3): 367-379.

Halliwell B, Gutteridge JMC. 2007. Free Radicals In Biology And Medicine. Ed ke-4. Oxford, UK: Oxford University Press.

Hanani E, Mun'im A, Sekarini R. 2005. Identifikasi senyawa antioksidan dalam spons Callyspongia sp. dari Kepulauan Seribu. Majalah Ilmu Kefarmasian 2(3): 127-133.

Harborne JB. 1987. Metode Fitokimia. Padmawinata K, Soediro I, penerjemah. Bandung: ITB. Terjemahan dari: Phytochemical Methods.

Huang B, Ban X, He J, Tong J, Tian J, Wang Y. 2011. Hepatoprotective and antioxidant activity of ethanolic extracts of edible lotus (Nelumbo nucifera Gaertn.) leaves. Food Chem. 120: 873-878.

Jaeschke H, Gores GJ, Cederbaum AI, Hinson JA, Pessayre D, Lemasters JJ. 2002. Mechanisms of hepatotoxicity. Toxicol.l Scie. 65: 166-176.

Jin YKJ, Russell RM, Aldini G. 2010. Antioxidant activity and oxidative stress: an overview. Di dalam: Aldini 
G, Yeum KJ, Niki E, Russell RM, editor. Biomarkers for Antioxidant Defense and Oxidative Damage: Principles and Practical Applications. Iowa, USA: Blackwell Publishing.

Karthikeyan DR, Manivasagam T, Subramanian P, Somasundaram ST, Anantharaman P, Balasubramanian T. 2008. Antioxidant activity of brown alga Padina boergesenii against carbon tetrachloride induced liver fibrosis in rats. Seaweed Res. Util. 30: 157-163.

Kiernan JA. 1990. Histological and Histochemical Methods: Theory and Practice. Ed ke-2. Kanada: Pergamon Press.

Klaunig JE, Corthals SM, Kamendulis LM, Philip BK. 2009. Role of The Kupffer Cell in Hepatotoxicity and Hepatocarcinogenesis. Di dalam: Sahu SC, editor. Hepatotoxicity from Genomics to in vitro and in vivo Models. West Sussex, England: John Wiley \& Sons Ltd.

Kumarappan C. Vijayakumar M, Thilagam E, Balamurugan $M$, Thiagarajan $M$, Senthil S, Das SC, Mandal SC. 2011. Protective and curative effect of polyphenolic extract from Ichnocarpus frutescense leaves on experimental hepatotoxicity by carbon tetrachloride and tamoxifen. Ann. of Hepat.10(1): 63-72.

Lotito SB, Fraga CG. 2000. Catechins delay lipid oxidation and alpha-tocopherol and beta-carotene depletion following ascorbate depletion in human plasma. Proceeding of The Society for Experimental Biology and Medicine 225: $32-38$.

Martin KR. 2006. Targeting apoptosis with dietary bioactive agents. Experimental Biology and Medicine 231: 117-129.

Middleton E Jr, Kandaswami C, Theoharides TC. 2000. The effects of plant flavonoids on mammalian cells: implications for inflammation, heart disease, and cancer. Pharmacology Review 52: 673-751.

Muriel P, Alba N, Perez-Alvarez VM, Shibayama M, Tsutsumi VK. 2001. Kupffer cells inhibition prevents hepatic lipid peroxidation and damage induced by carbon tetrachloride. Toxicology and Pharmacology 130:219226.

Noor YR, Khazali M, Syadipura INN. 2006. Panduan Pengenalan Mangrove di Indonesia. Bogor: Wetlands Internatinal.

Nugraheni M, Santoso U, Suparmo, Wuryastuti H. 2011. Potential of Coleus tuberosus as an antioxidant and cancer chemoprevention agent. International Food Research Journal 18(4): 1471-1480.

Panjaitan RGP. 2008. Pengujian aktivitas hepatoprotektor akar pasak bumi (Eurycoma longifolia Jack.). [disertasi]. Bogor (ID): Sekolah Pasca Sarjana, Institut Pertanian Bogor.

Pinzaru IA, Hădărugă DI, Hădărugă NG, Corpaş L, Grozescu I, Peter F. 2011. Hepatoprotective flavonoid bioconjugate/ $\beta$ - cyclodextrin nanoparticles:dsc-molecular modeling correlation. Digest Journal of Nanomaterial and Biostructure 6(4): 1605-1617.

Punitha SC, Rajasekaran M. 2011. Antioxidant mediated defense role of Wedelia calendulacea herbal extract against $\mathrm{CCl}_{4}$ inducedtoxic hepatitis. Journal of Applied Pharmaceutical Science 1(9): 111-115.

Quintieri L, Palatini P, Moro S, Floreani M. 2011. Inhibition of cytochrome P450 $2 \mathrm{c} 8$-mediated drug metabolism by the flavonoid diosmetin. Drug Metabolism Pharmacokinetics 26(6): 559-568.

Sahreen S, Khan MR, Khan RA. 2011. Hepatoprotective effects of methanol extract of Carissa opaca leaves on $\mathrm{CCl}_{4}$-induced damage in rats. $B M C$ 
Complement Alternative Medicine 11(48): 1-9.

Sen S, Chakraborty R, Sridhar1 C, Reddy YSR, De B. 2010. Free radicals, antioxidants, diseases and phytomedicines: current status and future prospect. International Journal of Pharmaceutical Science Review and Research 3(1): 91-100.

Sengupta M, Sharma GD, Chakraborty B. 2011. Hepatoprotective and immunomodulatory properties of aqueous extract of Curcuma longa in carbon tetra chloride intoxicated Swiss albino mice. Asian Pacific Journal of Tropical Biomedicine 1: 193-199.

Setzer WN. 2008. Non-intercalative triterpenoid inhibitors of topoisomerase ii: a molecular docking study. Compounds Journal 1: 13-17.

Sharma N, Shukla S. 2011. Hepatoprotective potential of aqueous extract of Butea monosperma against $\mathrm{CCl}_{4}$ induced damage in rats. In press: 1-11.

Stockham SL, Scott MA. 2002. Fundamentals of Veterinary Clinical Pathology. Ed ke1. Iowa state Pr. Blackwell Publishing Co. hlm. 433-486.

Suja SR, Latha PG, Pushpangadan P, Rajasekharan S. 2004. Evaluation of hepatoprotective effects of Helminthostachys zeylanica (L.) Hook against carbon tetrachloride-induced liver damage in Wistar rats. Journal of Ethnopharmacology 92(1): 61-66.

Thapa BR, Walia A. 2007. Liver funcion tests and their interpretation. Indian Journal of Pediatics 74(7):663-671.

Topcua T, Ertasb A, Kolakb U, Öztürk M, Ulubelen A. 2007. Antioxidant activity tests on novel triterpenoids from Salvia macrochlamys. ARKIVOC 7: 195-208.
Vadlapudi V, Naidu KC. 2009. Evaluation of antioxidant potential of selected mangrove plants. Journal of Pharmaceutical Research 2(11): 17421745.

Wang BJ, Liu CT, Tseng CP, Yu ZR. 2004. Hepatoprotective and antioxidant effects of Bupleurum kaoi Liu (Chao et Chuang) extract and its fractions fractionated using supercritical $\mathrm{CO}^{2}$ on $\mathrm{CCl}_{4}$-induced liver damage. Food and Chemical Toxicology 42(4): 609 617.

Wu X, Beecher GR, Holden JM, Haytowitz DB, Gebhardt SE, Prior RL. 2004. Lipophilic and hydrophilic antioxidant capacities of common foods in the United States. Journal of Agriculture Food Chemistry 52: 4026-4037

Yang J, Kim JS, Sa YJ, Kim MO, Jeong HJ, Yu CY, Kim MJ. 2011. Antioxidant, antibacterial and $\alpha$-glucosidase inhibitory activities of different extracts of Cortex moutan. African Journal of Biotechology 10(46): 94389444.

Yeum KJ, Russell RM, Krinsky NI, Aldini G. 2004. Biomarkers of antioxidant apacity in the hydrophilic and lipophilic compartments of human plasma. Archives. Biochemistry Biophysics 430: 97-10.

Yeum KJ, Beretta G, Krinsky NI, Russell RM. Aldini. 2009. Synergistic interactions of antioxidant nutrients in a biological model system. Nutrition 25(7-8): 839846.

Zhang ZS, Li D, Wang LJ, Ozkan N, Chen XD, Mao ZH, Yang HZ. 2007. Optimisation of ethanol-water extraction of lignans from flaxseed. Journal of Separation and Purification Technology 57: 17-24. 